\title{
Sexual Obedience and the Principle of no Harm
}

\author{
Iman Zeajeldi"1 \\ Hamid Reza Parhammehr2 \\ 1- Department of Religious Jurisprudence and Islamic law, Zabol University, Zabol, Iran \\ 2-Department of Private law, Zabol University, Zabol, Iran \\ *Corresponding author: 2223018@gmail.com
}

\section{Doi:10.5901/mjss.2015.v6n6s2p561}

\section{Abstract}

The Islamic law has appointed some duties that spouses have towards each other. These duties are based on good communication and friendly relationship. Spouses must attempt to strengthen family foundation, prepare a calm and enjoyable environment, and bring about the material and intellectual needs of each other. One of these needs is sexual need which can guarantee family stability, spouses' transcendence, and the generation survival if it is correctly met. In the Islamic law and consequently in the civil law of Iran, wife must respond affirmatively to her husband's sexual needs and must not avoid her duty. And if she avoids her duty without any plausible excuse, she will be considered as a delinquent (Nashezeh). That is why some scholars have resorted to the initial legal guides of the issue and concluded a special interpretation of the wife's obedience from her husband, in which avoidance form this duty is not allowed under any circumstances or excuses. However, as opposed to the traditional understanding that is resulted from superficial interpretations and has no legal justification, in accordance with the principle of no harm and enforcement of its provisions in spouses' relationship, wives are not obligated to adhere to absolute obedience from their husband's sexual needs but they are allowed to accomplish or avoid their duty depending on mental and physical status - which results from paying attention to the women's personality and individuality. This obedience must not be in contradiction with their mutual gratification and affection. It should also be kept away from inexcusable avoidance, malice, and obstinacy. By paying more precise attention to the meaning and implication of this argument and general principles and law of Islam, this interpretation cannot be emphasized on. By considering human dignity and women's personality in this duty, it should be accepted that the available contradictions lead us to restrict this guideline.

Keywords: sexual obedience; wife; family; sexual intercourse

\section{Statement of the Problem}

Family is the most important educational organization of the society and has vital importance for the individual and the society. A remarkable increase in the number of issues related to family problems indicates the presence of abnormalities if Iranian families. In families, wife and husband's interactions are major ones that follow them. Therefore, rise and fall of family depend on the relationship between wife and husband. Family problems take various dimensions each of which has specific reasons and causes. In a general classification, the spouses' dissatisfaction and conflict can be due to the abnormal behavior of one or both of them; in other words, they can result from the breach of family organization principles. Another possibility is that none of the spouses has been norm-breaker; however, family structural problems of the family have resulted in dissatisfaction and conflict.

Early observations and a large number of lawsuits have indicated that in tradition and public opinion, wife's sexual obedience (hereafter called specific obedience) from her husband is a remarkable setting for the spouses' family dissatisfaction and conflict.

Specific obedience sometimes is generally defined as the husband's headship over the family and respect for his decision in children's training and financial and moral control of the family, which includes a large number of examples. And sometimes it has a specific application and only refers to sexual principles and issues.

Due to the fact that lots of conflicts are originated from sexual obedience, and despite the fact that the present issue is complicated and has various critical aspects, the present study is an attempt to investigate the scope of specific obedience according to the jurists (i.e. Fuqaha) and generally the Islamic law in order to further and better understand the origin of the spouses' conflict and propose appropriate solutions to prevent and eliminate this problem. 


\section{Definition of Sexual Obedience}

Jurists consider sexual obedience as a dependent term and have provided no obvious explanation for it and they have referred to it through examples or hints (Sheikh Toosi, 2009). However, Shahid Sani has described it more clearly:

Obedience means that a wife must not separate herself and her husband and does not allot a specific time or place to sexual pleasure (Shahid Sani, 1993).

\subsection{The scope of sexual obedience}

In discussing the limits of specific obedience, the best solution is to refer to the proof evidence of the issue, which usually refers to the definition and limits of the issue.

\subsection{The reasons of sexual obedience}

In Fiqh texts, three reasons are referred to including the Holy Quran, the Sunnah, and consensus.

A. The Holy Quran: The most obvious definition and meaning of the issue can be taken from two verses of AlBaqara: you will be asked about menstruation, then reply: it is suffrage, so in menstruation days stay away from your wives / your wife is your land, so plow your land whenever you like (The Holy Quran).

As was observed, the interpretation of "your wife is your land, so plow your land whenever you like" is that wives should be sexually obedient to their husbands (Tabatabaee, 1994). In this interpretation, the expression "whenever/wherever you like" specifies the limits of the obedience. In this regard, some scholars' opinions are presented here.

1. In his interpretation, Ayashi has referred to some narratives like "wherever he wants" or "[he can get pleasure] deeply from her behind and front" where he has interpreted "whenever/wherever you like" as "the quality of enjoyment" and "time or place".

2. Ghomi has provided narratives like "enjoying the vulva" in the first and last days of menstruation necessitates payment of charity; therefore, he interpreted "whenever/wherever you like" as "time". However, in the Sunnah it is interpreted as "the quality of enjoyment" (Ghomi, 1411).

3. In his book "Tebyan", Sheikh Toosi has claimed that since most interpreters and scholars consider the word "whenever/wherever" as "place", interpreting "whenever/wherever you like" as "wherever you like" is wrong. He finally interpreted it as "where and how you like" and also "you can plow your land in whatever part you like" (Tabarasi, 1989). Tabarasi has referred to this interpretation in the community of Majma' Al-Javame' (Tabarasi, 1989 \& Tabarasi, 1988).

4. In Al-Bahrain community, Tarihi has mentioned three interpretations: "the quality of enjoyment", "the place of enjoyment", and "the time of enjoyment".

5. In the BookQuran principles, Ibn-Arabi has considered "whenever/wherever" as "the quality", "the place", and "the time" and he believes that jurists and scholars mostly vote for these three interpretations (Ibn Arabi, 1988 \& Gharbati, 1996).

6. The author of the Criterion believes that "whenever/wherever" is "a time expression" which is also used as a "place" word, too. When it means "time", the interpretation is "whenever you like" and if it means "place", it will be interpreted as "wherever you like". In any case, the conclusion is that "there is no limit". Especially, the expression "you like" prevents the word "as you like" from implying obligation because when something is on will, it is meaningless to assign obligations. On the other hand, according to the abovementioned verses, "your wife is your land" in sexual intercourse and interpretation of "land", it is clear that progress in intercourse depends on time and place and not the body parts.

And finally, the verse can be interpreted as: the developmental purpose of men's tendency towards women and the uterus as the place of human's origin and development is to provide a means to survive the generation; and if sexual intercourse is conducted accordingly, it is meaningless to restrict it to a specific time or place provided that it does not interrupt another obligatory (Tabatabaee, 1994).

However, despite the fact that there are disagreements over how to interpret and specify the restrictions, scholars' opinions can be summarized as: "whenever/wherever" is interpreted as both time and place and mentioned as an "absolute" word in this verse; therefore, men are allowed to sexually exploit women. Man can ask his wife for any kind of sexual pleasure anytime and anywhere (Tabatabaee, 1994).

However, it seems that first, the verse is meant to eliminate prohibition; that is after menstruation days sexual 
intercourse with women is not limited to any place or any time (Mozafar, 1989). However, the verse does not mean to determine whether any kind of sexual pleasure at any time and in any place is men's right or women's duty. In other words, it is aimed at removing the prohibition and not proving the right or the duty. Second, the verse is intended to state that women are like lands for generation survival which cannot be restricted to time or place. Therefore, it does not give the absolute right of sexual pleasure to men (Tabatabaee, 1994).

B. The Sunnah: In this regard, there are different narratives that can be referred to. Some of the narratives have been retrieved from the abovementioned verses of Al-Baqara Surah (212/213) and the explanation of the expression "whenever/wherever you like", which generally refer to "time, place, and quality". Most interpreters have also referred to these three interpretations (Ameli, 1983) all of which in our opinion are justifiable.

There are also several other narratives that are not included here.

However, by investigating the abovementioned narratives and other ones, it seems that although there are valid narratives on the issue, most of them are not in agreement with legal principles and do not have legal validity. However, if these weaknesses are ignored and just implications are taken into account, it can be stated that:

In these narratives, there is no evidence to suggest that wife should respond to her husband's sexual needs regardless of her physical, mental, and emotional readiness. Rather, these narratives suggest the wife not "refuse her husband as a result of malice and obstinacy". The word "refusal" in the narratives is interpreted as an excuse to refuse as a result of malice and obstinacy; therefore, if there is a valid excuse like physical, mental, and emotional ones, it is not considered as refusal because these conditions are not in her control and terminate the obligation (Noor Baha, 2004).

Moreover, there are some other narratives that state that "procrastinating" without any valid and acceptable excuse is to refuse and evade from the husband's need.

C. Consensus: There is consensus on that wife's obedience from her husband is obligatory and certain (Najafi, 1984). However, some jurists have reached a consensus on its limits as follow:

Obedience means that a wife must not separate herself and her husband and does not allot a specific time or place to sexual pleasure. Here, place can mean the whole of the woman's body which is pleasurable. In obedience, both preparation types are valid; however, the first one is more obvious (Shahid Sani, 1983)

Some have also defined complete obedience as: Obedience is to announce readiness through words or actions at any time and in any place such that if she refuses in a certain time or place, she does not deserve alimony. And if during marriage she keeps silent and does not announce her obedience from her husband and state in words that she is ready at any time and in any place and does not accomplish her word, she does not deserve alimony, which means that obedience in action is not sufficient (Shahid Sani, 1876).

By evaluating the abovementioned consensuses, it should be stated that consensus on this implication is not acceptable because:

First, according to the available narratives on the issue, this consensus is invalid evidence.

Second, the jurists' votes that are explicitly and implicitly against this implication abolish the consensus.

Third, past jurists ignored this extensive issue and a consensus cannot be conducted among them.

Up to here, justifications discussed by the Holy Quran, the Sunnah, and consensus have been summarized and according to the available contradictions among them, it can be stated that these reasons and justifications have not included the limits and restrictions for wives or husbands in sexual pleasure. Only its principle can be retrieved from these justifications and suspected cases cannot be clarified through them.

\subsubsection{The principle of no harm as the indicator of obedience restrictions}

The principle of no harm that is also called "no harm and loss" (Ameli, 1983), "no harm and loss in Islam" (Sheikh Sodduqi, 1982), and "no harm or loss to Muslims" (Ameli, 1983) is a certain and strong rule. The jurists and Osolis ${ }^{1}$ have referred to the Holy Quran and, the Sunnah, consensus, and intellect to prove it. This rule is used to control and modify other rules and is applicable in prayers and trading. It also plays a remarkable role in spouses' principles especially in "sexual obedience". To clarify the effect of this principle, its definition and implication should be taken into consideration.

\footnotetext{
${ }^{1}$ A group of Muslim scholars known as the Osolioon, they believe that the rulings of Islam should be drawn from its sources, meaning
} the Quran, the Sunnah, the Intellect and Consensus 


\subsection{The definition of the principle}

\subsubsection{The definition of loss and harm}

Khomeini has stated that the definition of loss is clear in the custom because it is compared to benefit, which includes financial and physical losses. However, it is not applicable when someone defames someone else. For instance, it is said that someone has lost in a trade or has taken a drug which was harmful. But in case of defamation, it is not said that someone is harmed or lost. Moreover, loss and harm have the same meaning; however, loss is used for financial and life cases but harm is applied for restriction, negligence, fault, and difficulty (Valaee, 2007).

Naeeni has stated that loss refers to intentional and unintentional but harm includes intentional ones. By comparing these two, it is concluded that loss is unintentional and harm refers to an intentional action. Khorasani has stated that loss and harm mean the same; however, loss refers to cases of finance, life, and reputation

\subsection{Types of loss}

Jafari has stated that loss is classified into four groups:

1. Loss caused by natural events.

2. Loss caused by other people resulting in interest contention, survival conflict, and animal desires and lust.

3. Loss caused by social and individuals laws and principles.

4. Loss caused by legal contention (Jafari, 1996: 100).

\subsection{Implication of the principle}

\subsubsection{Coverage of the principle of no harm over prayers and trading}

There is conflict over the applicability of the principle in prayers (Makarem Shirazi, 1993). The order of "general principality" in generality and extensiveness of the loss doer - on people and the legislator - and also the basis for appreciation of this principle which rejects people's acceptance of the legislator's damage of the principles rejects the debate and exclusiveness of the principle in trades. This can prove the application of the abovementioned principle in prayers and trades.

\subsubsection{Does harm refer to personal harm or common harm?}

Osolis believe that in this principle, harm is meant personal harm (Mostafavi, 1992), which is due to the traditional connotation of the word "harm" and prevents forging the principle of no harm. Therefore, in order to enforce the principle of no harm, specific conditions of each case should be taken into account.

Therefore, according to "the principle of no harm", which is a certain and strong rule, in any case - trade or prayer - that results in harm to the person, the principle terminates the harmful action. As a result, by investigating the usage cases of the words "harm and loss" which are mentioned in justification of the principle - in Islamic resources - it can be concluded that "loss" includes all damages imposed on someone and "harm" refers to cases that are interpreted as "abusing the right" (Khomeini, 1996). In addition to that, some scholars believe that damage includes any kind of loss in properties, reputation, respect, or life (Gharavi Naeeni, 2000) and also imposing stress, hardship, and emotional abomination (Khomeini, 1996).

\subsubsection{Principle of no harm has priority over judgment evidence}

Apparently, there is conflict between the principle of no harm and judgment evidence. In order to resolve the conflict, Osolis believe that the principle of no harm is dominant over judgment evidence; therefore, it has priority (Khooyi, 1972). However, some Osolis do not believe in the dominance of the principle of no harm over judgment evidence but consider it prior. This belief is originated from the point that preventing harm and loss is preferred.

\subsubsection{Dominance of the principle of no harm in justification of sexual obedience}

As was discussed, in Islamic law "the right of sexual pleasure" is certainly the man's, which is justifiable by referring to 
Quranic evidence, the narratives, and consensus. However, referring to this right sometimes causes harm to the wife and she will be imposed financial or life loss, stress, or emotional abomination. For instance, if a wife due to a heart disease may be subject to heart failure, or due to the death of one of her loved ones is not ready to have sex, or he husband asks for sex in an inappropriate place, where there may be some intruder, which results her to be stressed, the wife can disobey. By the virtue of the principle of no harm, this action can be excluded from the realm of sexual obedience. Moreover, in Verse 5, Talaq Surah, it is stated that, "never force your wife and do not put her under stress and pressure", which again supports the principle of no harm in marital relationships.

\subsubsection{Criteria for sexual pleasure}

In the debate on the reference of sexual obedience, there is a question: What are the criteria of sexual pleasure that are legally appropriate or at least not inappropriate? To respond to this question, it can vividly be stated that according to the rule of justice, mutual rights of couples, and good communication between them, and the principle of no harm, the "convention" of every period is the criterion. In other words, marital relationships are decided in accordance to the women's personality - both as humans and individuals - that are defined based on the particular conventions of any time or place. In this judgment; however, the requirements of good communication cannot be specified because social customs and traditions, civilization, and religious morality of any group of people determine such requirements. Therefore, in brief it can be stated that sexual relationships should be specified in a way that they are not in conflict with the affection between the spouses and kept away from delinquency. Despite its difficulty and sensitivity, this convention can be converted into a binding rule by the legislator, so its enforcement will be assured (Katouzian, 2006).

\section{Conclusion}

It is concluded that women's specific obedience is a certain issue and proved by Islamic jurists' consensus and scholars; however, in regard with its reference and observation it should be stated that despite of the apparent Quranic justifications and those mentioned in the narratives on the issue, priority is given to the principle of no harm. In accordance with the second implication of this principle, in case of physical and mental barriers, the wife should not be considered as delinquent and deprived from alimony. As opposed to the traditional understanding that is resulted from superficial interpretations and has no legal justification, in accordance with the principle of no harm and enforcement of its provisions in spouses' relationship, wives are not obligated to adhere to absolute obedience from their husband's sexual needs but they are allowed to accomplish or avoid their duty depending on mental and physical status - which results from paying attention to the women's personality and individuality. This obedience must not be in conflict with their mutual gratification and affection. It should also be kept away from inexcusable avoidance, malice, and obstinacy.

\section{References}

The Holy Quran

Ibn Maje, Abi Abdulla (1975). Traditions. vol. 1. Dar Al-Ahya Al-Turath Al-Arabiya: Beirut.

Khomeini, R. A. (1996). Ten letters. vol. 1. The Institute of Publishing Imam Khomeini's works.

Khooyi, S. A. (1972). Mesbah Al-Osul. vol. 2. Dar Az-Zahra: Beirut.

Shahid Sani, Z. A. (1993) Albahiya Almarziyah. vol 5. Islamic Knowledge Institution: Ghom.

Shahid Sani, Z. A. (1983). Masalek Alfaham. vol. 1. Islamic Knowledge Institution: Ghom.

Shahid Sani, Z. A. (1876). Al-Behjah Al-Marziyah. vol. 2. Islamic Knowledge Institution: Ghom.

Sheikh Soddugh (1982). On those who do not attend the pious. Dar Al-Islam.

Sheikh Toosi, Abu Jafar (2009). Mabsoot in Imamate Figh. vol 6. Al-Maktab Al-Mortzaviya Al-Ihya Asar Al-Jafariya: Tehran.

Tabatabaee, M. H. (1994). Criteria in interpretation of the Quran. vol. 2. Ismaeeliyan Institution: Ghom.

Tabarasi, A. A. (1989). Tebyan. vol. 2. Dar Al-Kotob Al-Ilmiyah: Ghom.

Tabarasi, A. A. (1989). Javam' Al-Jame'. vol. 1. The center of managing the seminary and publication of Tehran University.

Tabarasi, A. H. (1988). Majma' Al-Bayan. vol. 2. Dar Al-Ma'rafa: Beirut.

Tarihi, F. A. Majma' Al-Bahrain. vol. 1. Almaktaba Al-Mortazaviyah: Tehran.

Ameli, M. H. (1983). Vasael Shia. vol. 14. Maktab Al-Islamiyah: Tehran.

Ameli, M. H. (1983). Vasael Shia. vol. 15. Maktab Al-Islamiyah: Tehran.

Gharavi Naeeni, M. H. (2000). Maniyah Al-Talib. vol. 2. Mortazavi Publication.: Najaf.

Ghomi, A. H. (1411). Ghomi interpretation. vol. 1. Dar Al-Sorur: Beirut.

Katouzian. N. (2006). Family law. vol. 1. Enteshar Corporayion: Tehran.

Mostafavi, M. K. (1992). Principles. Islamic Publication Institute. 
Mozafar, M. R. (1989). Fiqh principles. vol. 1. Islamic Preaching Office: Ghom.

Makarem Shirazi, N. (1993). Fiqh principles. vol. 1. Imam Amir Al-Moemenin: Ghom.

Najafi, M. H. (1984). Javahir Al-Kalam. vol. 1. Islamic Books Institution: Tehran.

Najafi, M. H. (1984). Javahir Al-Kalam. vol. 31. Islamic Books Institution: Tehran.

Noor Baha, R. (2004). Issues in public criminal law. vol. 10. Dadafarin Publication: Tehran.

Valaee, I. (2007). Explanatory dictionary of Fiqh terms. Ney Publication. 